\title{
DIDACTICS
}

$\infty$

\author{
Klaudia Gąsior \\ Maria Curie-Skeodowska University (UMCS) in Lublin \\ KLAUDIA.GASIOR@ONET.EU
}

\section{Classroom Interaction in Oral Language Learning Events Created by EFL Storytelling-based Games}

\begin{abstract}
The paper aims at discussing some examples of classroom interaction in the context of playing "One Word/Sentence at a Time" and "Story Cubes" games by Polish secondary school students of English. First, it gives an overview of definitions and major types of classroom interaction. Second, it presents the opportunities for classroom interaction offered by a game-like environment. Then, the action research study conducted with a group of EFL learners is presented. The participants were recorded in the course of four storytelling-oriented lessons over a period of two weeks. Then, the stories were transcribed and analysed. Summing up the data gathered throughout the study, it is evident that the games offer a highly interactive FL classroom environment in which various categories of student-talk intertwine with teacher-talk.
\end{abstract}

Keywords. classroom interaction, storytelling, games, EFL speaking, secondary school students.

\section{Introduction}

There has been little agreement among researchers as to the investigation of the concept of classroom interaction ${ }^{1}$. While some scholars suggest that the research on $\mathrm{CI}$ has been carried out since the 1930s or 1960s (Howe 1997, 7; Skukauskaite et al. 2015, 44), some of them claim that this phenomenon has generally been understudied (Ohlberger and Wegner 2013,35). However, what academics unanimously agree upon is that classroom interaction is an important component of learning and teaching (Creemers and Kyriakides 2008, 18; Losey 1995, 284; Nisa 2014, 124; Ohlberger and Wegner

1 In this article classroom interaction is also referred to as CI. 
2013, 35; Tsui 1995, 12; Wieser 2013, 123). To be more precise, it is believed to play a significant role in foreign language education since there must be some communication between learners and their teachers for learning and teaching to take place. Even though the significance of meaningful communication in a foreign language classroom has been widely discussed by theoreticians, there is a persevering problem that daunts most language classrooms. It concerns overwhelming dominance of a teacher over his or her students who are usually given freedom to utter only single, one-word or one-sentence, utterances (Van Lier 1988, 3). As a result, the actual teaching that should encompass an exchange of knowledge and experiences between learners and teachers is, in fact, replaced with nothing but, as Beutel $(2010,80)$ defines it, "content delivery". According to Ohlberger and Wegner $(2013,35)$ and many other scholars (Beutel 2010, 86; Howe and Abedin 2013, 326; Li et al. 2011, 14; McCrory Calarco 2013, 125), however, effective lessons employ various kinds of interaction which make all classroom actors equally, or almost equally, active participants of the learning process. In other words, they are all expected to contribute to classroom discourse evenly in order to avoid situations in which growing supremacy of one speaker overshadows his or her interaction partners (Chiu 2013, 127).

Following the authors who discuss the concept in question (e.g. Beutel 2010; Bokhove 2018; Hanghoj and Brund 2011; Howe and Abedin 2013; Łęska 2008; Nisa 2014; Ohlberger and Wegner 2013; Smith and Higgins 2006; Tsui 2001), the paper draws attention to the importance of $\mathrm{CI}$ in foreign language learning and aims to prove that the three storytelling-based games that were selected for the purpose of the action research study diversify teachers' and students' in-class oral performance. The paper has been divided into two complimentary parts. The first one offers theoretical background to the issue of classroom interaction whereas the second one describes an action research study in which the three games, "One Word at a Time", "One Sentence at a Time" and "Story Cubes", were used with a view to maximizing the participants' foreign language speech production.

Therefore, the objectives of the paper are as follows: (1) to provide an overview of the definitions and types of classroom interaction; (2) to list the examples of interaction supported by games and, finally, (3) to enumerate the types of classroom interaction created by the games mentioned above. We refer to the relevant fragments of the transcripts in order to validate our claims on the categories of classroom interaction created by the games in question.

\section{Concept of classroom interaction}

No clear-cut definition of classroom interaction is available as theoreticians and practitioners describe this concept in a variety of ways. Nevertheless, there is no doubt that for a phenomenon to be termed classroom interaction, it ought to take place between learners and teachers in school settings (Tsui 2001, 120; Wieser 2013, 122). Since 
teachers and their students influence each other with respect to behaviours they display, language they use or knowledge they share, Łęska's $(2008,14)$ analogy between classroom interaction and "a process of continuous mutual influence and modification" in the context of defining CI seems perfectly natural. A similar stance to the concept of classroom interaction is adopted by Tsui (1995: 5). According to her, the concept shares many similarities with everyday communication in the sense that classroom interaction, just as ordinary day-to-day conversations, is based on finding compromise between interlocutors. Another researcher who draws attention to the inter-relationship between classroom actors is Nisa $(2014,124)$. He explains that they take certain actions in order to get reactions from their interlocutors.

Classroom interaction can be also discussed in the context of factors that structure the flow of interaction itself. Following Brown $(2001,165)$, who describes classroom interaction as "collaborative exchange of thoughts, feelings, or ideas between two or more people, resulting in a reciprocal effect on each other", it is justified to claim that what alters the course of interaction in the classroom is a set of behaviour-related aspects of human life (Tenorth and Tipelt 2007, 344). Since CI is a human-centred phenomenon affected by the behaviours of interlocutors, it is obvious that gestures and facial expressions, which are the key components of a conversation, are also believed to structure interaction (Köck 1994, 333). Therefore, what characterises the phenomenon of $\mathrm{CI}$ are the processes of continuous adaptations that take place on the part of teachers and learners.

There are also other terms that researchers use to refer to the concept under discussion. Flanders (1970 after Li et al. 2011, 3), for instance, compares the events taking place between learners and teachers to a set of oral scenarios that unfold in a sequential manner. Likewise, the definition "a dialogue not limited to talk" may be also employed with reference to CI (Scott and Ametller 2007 after Bokhove 2016, 18). It points to the fact that what is a common feature for both classroom interaction and a dialogue is the reciprocal character of verbal exchanges. Such a view implies that for utterances to be termed CI, they have to be followed by responses from other speakers (Howe and Abedin 2013, 327). Therefore, it can be concluded that not all teachers' and students' statements can be automatically regarded as instances of classroom interaction since a verbal reaction from at least one of the listeners is always required.

On the other hand, classroom interaction might be also considered in terms of "interactive practices" that are discussed by Hall (1995). This researcher (Hall 1995, 38) puts an equality sign between $\mathrm{CI}$ and the idea of interactive practices, arguing that both of them can be defined as "recurring episodes of purposeful, goal-directed talk which are significant to the establishment and maintenance of a group or community". It seems obvious now that classroom interaction can be compared to a multilateral talk that is not only aimed at achieving particular goals, but also establishing rapport and maintaining the feeling of community between speakers.

It is worthwhile mentioning here that classroom interaction has been frequently contrasted by many researchers with genuine interaction (Nunan 1987; Rod 1988; Ri- 
vera 2010; Seedhouse 1996). Some of the studies conducted in 1980s and 1990s, which aimed to investigate communicative competence, have reported that the patterns of interaction emerging during foreign language classes resemble classroom interaction rather than genuine interaction. Interestingly, the former is not believed to be effective enough in improving FL learners' communication skills (Nunan 1987, 144; Seedhouse 1996, 16-17). Such a view of the minor role of classroom interaction in developing students' competence in a foreign language given by Nunan (1987) and Seedhouse (1996) clashes with Hall's (1995) concept of interactive practices mentioned earlier in the article. As already stated, Hall $(1995,38)$ equates classroom interaction with the notion of interactive practices, supporting at the same time the view that "much communicative leaming in language classrooms is realized through engagement in regularly occurring interactive practices". Although classroom and real interaction do not develop similar patterns, the former still raises some possibilities of increasing students' language competence.

It should be evident now that classroom interaction may be defined in a variety of ways. Even though some of these approaches to CI seem diverse, there is one feature common to all of them - it is a social aspect of interaction which manifests itself in a number of reciprocal adjustments whose aim is for speakers to match their language or behaviour to that of their interlocutors. For the purpose of a game-oriented character of the action research study, an approach to classroom interaction proposed by Hall (1995) has been adopted. To be more precise, CI is understood here as a goal-oriented talk in which the speakers', that is the players', task is to win the game by telling a grammatically and logically correct story.

Having provided selected definitions of classroom interaction, it is important now to consider its major kinds. Ohlberger and Wegner $(2013,35)$, for instance, differentiate between seven types of classroom interaction. They include such categories of CI as, for example, teacher-student-talk, student-teacher-talk, presentation, lecture or answering chain. Interestingly, even though CI might be grouped into several categories, it is most often only the two from the list, that is teacher- and student-talk, that generate a considerable interest among teaching professionals. By no means exhaustive, Table 1 lists the selected examples of categories explored by Flanders (1970), Brown (2001), Smith and Higgins (2006) or Ohlberger and Wegner (2013).

Interestingly, the categories of classroom interaction presented above are not equally supported by all researchers. For example, having adopted the view on $\mathrm{CI}$ as a dialogue between teachers and students, in which an utterance is followed by a reaction and another utterance, the assignment of praising to the subcategory of teacher-talk can be questioned (Bokhove 2018, 18). Nevertheless, while looking at classroom interaction from the perspective of gaining language and content knowledge as well as improving social skills, this type of interaction should not be easily dismissed (Brown 2001, 173). For the purpose of the present paper, however, Brown's (2001) categorization of the kinds of classroom interaction has been adopted in order to analyse the three games employed in the study with respect to the types of CI. 
Pobrane z czasopisma New Horizons in English Studies http://newhorizons.umcs.pl Data: 26/04/2023 12:23:37

Classroom Interaction in Oral Language Learning Events...

Table 1. The categories of classroom interaction

\begin{tabular}{|c|c|c|}
\hline & \multicolumn{2}{|c|}{ Category of classroom interaction } \\
\hline $\begin{array}{c}\text { Flanders } \\
(1970 \text { after Li et al. } \\
2011,5)\end{array}$ & $\begin{array}{l}\text { I. Teacher talk - Indirect } \\
\text { influence: } \\
\text { - } \quad \text { Accepting feelings } \\
\text { - Praising/encouraging } \\
\text { - } \quad \text { Accepting/using students, } \\
\text { ideas } \\
\text { - Asking questions }\end{array}$ & $\begin{array}{l}\text { II. Teacher talk - Direct } \\
\text { Influence: } \\
\text { - } \quad \text { Lecturing } \\
\text { - } \quad \text { Giving directions } \\
\text { - } \quad \text { Criticizing/justifying } \\
\text { authority } \\
\text { III. Student talk: } \\
\text { - } \quad \text { Response } \\
\text { - } \quad \text { Initiation } \\
\text { - } \quad \text { Confusion }\end{array}$ \\
\hline $\begin{array}{c}\text { Brown } \\
(2001,170)\end{array}$ & $\begin{array}{l}\text { I. Teacher talk: } \\
\text { - } \quad \text { Dealing with feelings } \\
\text { - } \quad \text { Praising } \\
\text { - } \quad \text { Using students' ideas } \\
\text { - } \quad \text { Asking questions } \\
\text { - } \quad \text { Giving information } \\
\text { - } \quad \text { Giving directions } \\
\text { - } \quad \text { Criticizing }\end{array}$ & $\begin{array}{ll}\text { II. } & \text { Student talk: } \\
\text { - } & \text { Specific response } \\
\text { - } & \text { Open-ended response } \\
\text { - } & \text { Silence } \\
\text { - } \quad \text { Confusion } \\
\text { - } \quad \text { Laughter } \\
\text { - } \quad \text { Response in L1 } \\
\quad \text { Non-verbal response }\end{array}$ \\
\hline $\begin{array}{l}\text { Smith and Higgins } \\
\qquad(2006,488)\end{array}$ & $\begin{array}{ll}\text { I. Teacher: } \\
\text { - } & \text { Asking open/closed } \\
& \text { questions } \\
\text { - } & \text { Repeating/uptaking } \\
& \text { questions } \\
\text { - } & \text { Probing } \\
\text { - } & \text { Evaluating } \\
\text { - } & \text { Explaining } \\
\text { - } & \text { Directing } \\
\text { - } & \text { Refocusing } \\
\text { - } & \text { Pausing } \\
\text { - Interrupting } & \text { General talk }\end{array}$ & $\begin{array}{l}\text { II. Pupil: } \\
\text { - } \quad \text { Answering } \\
\text { - } \quad \text { Making choral response } \\
\quad \text { Making spontaneous } \\
\text { contribution }\end{array}$ \\
\hline $\begin{array}{l}\text { Ohlberger and Wegner } \\
\qquad(2013,35)\end{array}$ & $\begin{array}{l}\text { I. Teacher-student-talk } \\
\text { II. Student-teacher-talk } \\
\text { III. Presentation } \\
\text { IV. Lecture }\end{array}$ & $\begin{array}{l}\text { V. Murmur phase } \\
\text { VI. Group talk } \\
\text { VII. Answering chain }\end{array}$ \\
\hline
\end{tabular}

\section{Types of game-based classroom interaction}

Even though games differ in terms of rules, it is a variety of interactions and opportunities to communicate that they are said to offer (Boarcas 2014, 376). Apart from obvious instances of pair- and group work (Wright et al. 2006, 3), there are also other kinds of interaction involved. This section discusses the major categories of interaction established by gamified classroom work.

One may isolate three types of student-student interaction. Siek-Piskozub (1994, 17) categorizes them into rivalry, cooperation and compromise. Rivalry is especially 
valuable from the point of view of linguistic development since thanks to a high level of competition, participants become more attentive to their language use. Cooperation-based games, on the other hand, usually take the form of gap-information tasks in which students need to work together to reach their goals. To achieve that, they frequently rely on a variety of strategies such as negotiation or deduction. Compromise is another type of interaction which games can be based on. Coming to a compromise implies that all participants have presented their opposing arguments and have managed to find a common ground by accepting the most logically-sound solutions (SiekPiskozub 1994, 17).

It is also the teacher who may occupy different positions in the classroom. Over the years, various scholars have provided differing conceptualizations of teachers' roles, which, as it will be shown later, share a lot of similarities. Byrne's $(1987,13)$ classification of teachers' roles from the late 1980s distinguishes between teachers taking on the roles of conductors, monitors, stimulators, or managers. Siek-Piskozub (1994, 19), on the other hand, uses different terms while describing teachers' roles. According to her, having become a leader, the teacher is accountable for communicating the proceedings of a game by talking to the representatives of groups or the whole class. If his or her mediation in the game is not obligatory, the teacher can function as an observer, withdrawing from the game and silently observing students. Should any conflicts arise, the teacher may always become an arbiter in order to help players solve misunderstandings. Alternatively, teachers may join their students and accept the role of ordinary participants if, for instance, there are not enough players in a classroom.

A more recent classification similar to those of Byrne's (1987) and Siek-Piskozub's (1994) is offered by Hanghoj and Brund $(2011,127)$. They differentiate between teachers as instructors, playmakers, guides, and evaluators. While the definition of a teacher as an instructor is rather self-explanatory - the teacher who performs such a role is to equip the students with comprehensive linguistic knowledge - the notions of playmakers and guides seem to bear clear resemblance to teachers as leaders discussed earlier. Those teachers who become evaluators take responsibility for assessing the game as well as performance of their pupils.

While analysing the stories recorded and transcribed in the course of the four-lesson action research study, the classification of student-student and teacher-student interaction proposed by Siek-Piskozub (1994) has been implemented.

\section{The action-research study}

In this section we present the study in question whose objective is to prove that the games employed during English lessons helped to diversify classroom interaction. 


\subsection{Subjects}

The subjects of the study were 12 seventeen-year old intermediate students of English from Maria and Jerzy Kuncewiczowie Secondary School in Lublin, Poland. Seven girls and five boys participated in the action research study. The majority of the students had been learning English for ten years.

\subsection{Materials}

The basis for the study to be conducted and analysed were four lessons, the recordings and transcripts of the participants' stories as well as a set of questionnaires designed by the current author. Each lesson was presented to the students in a form of a worksheet containing a range of tasks.

\subsection{Procedure}

A group of 12 students met twice a week for 45 -minute sessions for the period of two weeks. Before the study proper took place, a pre-study questionnaire was given to the secondary school students. Its aim was to collect some information about their English language learning experiences. Afterwards, a sequence of four lessons was conducted. During the first two meetings, the students could tell a story while playing classroom games, that is "One Word/Sentence at a Time." During Lessons Three and Four, however, they related their own stories while playing "Story Cubes" games in groups of four. It was also during an extra meeting, which took place a week later, that the poststudy questionnaire was administered. It aimed to find out what the learners' impressions of the lessons were after they had been exposed to a different kind of instruction, that is the use of storytelling-based games.

\subsection{Results and discussion}

There were ten recordings of the students' stories made in the course of four storytelling-based lessons. Let us now look at and analyse the transcripts selected for the purpose of the present paper.

\subsection{1 "One Word at a Time" game}

It was during Lesson One that the students were invited to tell a story by adding either a word or a full stop while playing "One Word at a Time" game. Most of the students had a chance to add a word twice. The game progressed in the way presented in Transcript 1. 
Pobrane z czasopisma New Horizons in English Studies http://newhorizons.umcs.pl Data: 26/04/2023 12:23:37

\begin{tabular}{|c|c|c|}
\hline Turn & Person & Transcript \\
\hline 1 & S1 & I. \\
\hline 2 & S2 & Noticed. \\
\hline 3 & S3 & {$[\ldots]$ (a moment of hesitation) $[\ldots]$} \\
\hline 4 & $\mathbf{T}$ & I noticed. \\
\hline 5 & S3 & {$[\ldots]$ (a moment of hesitation) [...] } \\
\hline 6 & $\mathbf{T}$ & Something? I noticed something. \\
\hline 7 & S3 & Just. \\
\hline 8 & $\mathbf{T}$ & Aha. \\
\hline 9 & S4 & Happen. \\
\hline 10 & $\mathbf{T}$ & Just something happen. Aha. \\
\hline 11 & S5 & To. \\
\hline 12 & $\mathbf{T}$ & You may always say full stop when this is the end of the sentence \\
\hline 13 & S6 & My friend. Może tak być? \\
\hline 14 & $\mathbf{T}$ & $\begin{array}{l}\text { We may say full stop. This is the end of the sentence and the second } \\
\text { person continues starting a new sentence. You start with the subject }[\ldots]\end{array}$ \\
\hline 15 & S6 & Aaa $[\ldots]$ no tak, bo koniec zdania. Kropka. \\
\hline 16 & S7 & We. \\
\hline 17 & $\mathbf{T}$ & Okay. \\
\hline 18 & S8 & Go. \\
\hline 19 & $\mathbf{T}$ & Went because that's the past form. \\
\hline 20 & S9 & Were going. \\
\hline 21 & S10 & But only one. We were $[. .]$. \\
\hline 22 & $\mathbf{T}$ & Going. \\
\hline 23 & S11 & To. \\
\hline 24 & $\mathbf{T}$ & To. \\
\hline 25 & S12 & To the library. \\
\hline 26 & $\mathbf{T}$ & Okay. We were going to the library. \\
\hline 27 & S1 & To. \\
\hline 28 & $\mathbf{T}$ & To. What's the purpose? \\
\hline 29 & S2 & Borrow? \\
\hline 30 & $\mathbf{T}$ & To borrow, yeah \\
\hline 31 & S3 & {$[\ldots]$ (a moment of hesitation) $[\ldots]$ books. } \\
\hline 32 & S4 & For school. \\
\hline 33 & $\mathbf{T}$ & $\begin{array}{l}\text { We've got two words, but that's okay. Do we continue the sentence or do } \\
\text { we say full stop? }\end{array}$ \\
\hline 34 & S5 & Hmmm [...] because. \\
\hline 35 & S6 & I. \\
\hline 36 & S7 & I want. \\
\hline 37 & $\mathbf{T}$ & Because I wanted to. That's the story set in the past. \\
\hline 38 & S8 & Do. \\
\hline 39 & S9 & Homework. \\
\hline 40 & $\mathbf{T}$ & Okay. I think we can stop here. Thank you! \\
\hline
\end{tabular}

Transcript 1. "One Word at a Time" game played by the participants during Lesson One $(2 \min 20 \mathrm{sec})$ 
Playing "One Word at a Time" proved to be problematic for the students. It was probably the lack of co-text and context which made it difficult for the participants' to contribute to the game. Even though the story consisted of only 25 words, that is two sentences, it took them more than 2 minutes to complete it. The reason behind that might have been twofold. First, most of the participants needed a lot of time to provide the right word. Second, it was the teacher whose input was significant. She tried to assist her students by either repeating everything that had already been said or by providing extra ideas to help the tellers complete their story.

\subsection{2 "One Sentence at a Time" game}

The subjects played "One Sentence at a Time" game during Lesson Two. Instead of producing a word, each of the participants was expected to add one sentence to the story. The learners played two rounds of the game, that is almost all of them formulated one sentence twice. Transcript 2 presents oral language samples produced by the subjects during the game.

\begin{tabular}{|c|c|c|}
\hline Turn & Person & Transcript \\
\hline 1 & S1 & I was sitting in the classroom. \\
\hline 2 & S2 & {$[\ldots]$ (a moment of hesitation) $[\ldots]$} \\
\hline 3 & $\mathbf{T}$ & And maybe someone came to the room? \\
\hline 4 & S2 & Teacher came to the $[\ldots]$ (a moment of hesitation) $[\ldots]$ \\
\hline 5 & $\mathbf{T}$ & To the class. \\
\hline 6 & S3 & hmm $[\ldots]$ and she $h m m[\ldots]$ \\
\hline 7 & $\mathbf{T}$ & What was her mood? Was she happy? Was she sad? \\
\hline 8 & S3 & And she was sad. \\
\hline 9 & S4 & Because we were playing on the phones. \\
\hline 10 & $\mathbf{T}$ & $\begin{array}{l}\text { She was sad because the students were using the phones excessively }[\ldots] \\
\text { too much. }\end{array}$ \\
\hline 11 & S5 & The students were unhappy. \\
\hline 12 & S6 & {$[\ldots]$ (a moment of hesitation) $[\ldots]$} \\
\hline 13 & $\mathbf{T}$ & What was the lesson? Was it a Biology lesson? Polish lesson? Maths? \\
\hline 14 & S6 & Polish lesson \\
\hline 15 & S7 & And she started yelling at us. \\
\hline 16 & S8 & We put away $[\ldots]$ our phones. \\
\hline 17 & $\mathbf{T}$ & Okay. You put away your phones and stopped using them. \\
\hline 18 & S9 & And the lesson began. \\
\hline 19 & $\mathbf{T}$ & What were you discussing? \\
\hline 20 & S10 & We were reading "Dziady"? \\
\hline 21 & S11 & {$[\ldots]$ (a moment of hesitation) $[\ldots]$} \\
\hline 22 & $\mathbf{T}$ & Did you enjoy the story as a class? \\
\hline 23 & S11 & The teacher prepared for us a short test. \\
\hline 24 & S12 & She wanted to check if we read the book. \\
\hline
\end{tabular}




\begin{tabular}{l|cl|}
25 & T & Yes. Great. \\
26 & S1 & She gave us the tests. \\
27 & S2 & We started writing. \\
28 & S3 & It was difficult (laugh) \\
29 & T & Yeah (laugh). \\
30 & S4 & Suddenly, we heard an alarm. \\
31 & S5 & {$[\ldots]$ some people $[\ldots]$} \\
32 & T & Yes. What were they doing? \\
33 & S5 & They were shouting. \\
34 & T & Great. \\
35 & S6 & There was a fire. \\
36 & T & What a tragedy! (laugh) \\
37 & S7 & We left the classroom. \\
38 & T & Yeah. What happened next? \\
39 & S8 & {$[\ldots]$ (a moment of hesitation) $[\ldots]$ and we didn't write the test (laugh). } \\
\hline
\end{tabular}

Transcript 2. "One sentence at a time" game played by the participants during Lesson Two $(3 \min 25 \mathrm{sec})$

In contrast to the storytelling-based game employed previously, "One Sentence at a Time" proved to be less challenging for the students. Even though the load placed on the players was slightly heavier as they were obliged to add one sentence to their story, it proved to be a more manageable task for them. First of all, despite the fact that there were two rounds of the game and they were to create longer sentences, the students took only 3 minutes and 25 seconds (only 1 minute longer than in "One Word at a Time" game) to finish their story. Second, storytelling itself progressed more smoothly. There were fewer pauses and the storytellers committed fewer mistakes while providing the past forms of regular and irregular verbs.

It is also useful to analyse here the teacher's contribution to the game. It can be presumed that it was because of her comments that the students were more successful. As shown in Transcript 2, teacher-talk served three functions. The first of them was that of providing an idea which the storytellers could refer to. The second function was that of summarising what had already been said by the students. The third function of the teacher's comments was that of praising and fostering the student's confidence.

\subsection{3 "Story Cubes" games}

The students played "Story Cubes" games during Lessons Three and Four. The words highlighted in Transcript 3 were the pictures that came from nine dice that the students had thrown before telling their story. Since the level of the participants' linguistic competence differed, the logical and grammatical quality of their utterances might have varied substantially. Such individual differences in the command of English are reflected in the transcripts below. 


\begin{tabular}{|c|c|c|}
\hline Turn & Person & Transcript \\
\hline 1 & S1 & Last Monday I was travelling to the mountains (1) [...] \\
\hline 2 & $\mathbf{T}$ & Okay, I was travelling to the mountains. Done. \\
\hline 3 & S2 & I noticed lots of birds. Some of them were eating seeds (2). \\
\hline 4 & $\mathbf{T}$ & Okay, perfect. Two sentences at a time. That's also possible! \\
\hline 5 & S3 & $\begin{array}{l}{[\ldots] \text { (a moment of hesitation) }[\ldots] \text { Then I want to saw the bird to my }} \\
\text { friend }[\ldots]\end{array}$ \\
\hline 6 & $\mathbf{T}$ & Okay. I wanted my friend to see the bird. Which picture is it? \\
\hline 7 & S3 & I pointed to the bird (3). \\
\hline 8 & S4 & {$[\ldots]$ (a moment of hesitation) $[\ldots]$} \\
\hline 9 & $\mathbf{T}$ & Maybe what was your friend's reaction? \\
\hline 10 & S4 & My friend was confused (4). \\
\hline 11 & S1 & [...] when he noticed a submarine (5) in the mountains. \\
\hline 12 & S2 & $\begin{array}{l}\text { [...] (a moment of hesitation) he drove the car (6) on seeing the } \\
\text { submarine. }\end{array}$ \\
\hline 13 & $\mathbf{T}$ & Aham. And what did you do on seeing your friend drive away? \\
\hline 14 & S3 & I was going down the stairs (7). \\
\hline 15 & $\mathbf{T}$ & And what happened afterwards? \\
\hline 16 & S4 & I found a crown (8). \\
\hline 17 & S1 & I put it on my head and drank a cup (9) of wine. \\
\hline 18 & $\mathbf{T}$ & Okay. Thank you very much! \\
\hline
\end{tabular}

Transcript 3. "Story Cubes" game played by Group 2 during Lesson Three (2 min $39 \mathrm{sec})$

Most of the storytellers needed a fair deal of time to add the next sentence to their stories. Such pauses were the result of the students' hesitation or confusion and they either indicated that the students were thinking what to say next or they were waiting for the teacher to give them some practical hints for their story to be continued.

During the last lesson the participants also played "Story Cubes" games. The transcript below presents oral language samples produced by them.

\begin{tabular}{c|cl} 
Turn & Person & \\
\hline 1 & S1 & It was raining (1) and I was very angry and confused. \\
2 & S2 & I played on computer games (2). \\
3 & S3 & I lost my necklace (3) while playing the computer game. \\
4 & T & You lost your necklace while playing the game? \\
5 & S3 & No tak! (laugh) \\
6 & T & Oh, I see! You were so engaged in playing the game! (laugh) Great! \\
7 & S4 & And I lost my crown (4) too! (laugh) \\
8 & S1 & Because of weather I am angry too because I was ... nie. I wanted \\
9 & slept on the ... \\
10 & T & I wanted to sleep. \\
11 & S1 & Yeah. I wanted to sleep in the tent (5). \\
12 & S3 & I was eating from my sack (6). \\
13 & S4 & I stopped eating and throwed a phone (8). \\
14 & T & Yes. You threw the phone. What happened next? \\
15 & S1 & I started crving (9). \\
16 & T & Okay, one minute thirty one seconds.
\end{tabular}

Transcript 4. "Story Cubes" game played by Group 2 during Lesson Three (2 min $17 \mathrm{sec}$ ) 
As far as the second round of playing "Story Cubes" game is concerned, one may state that it was much more successful. The players were more fluent with the good recall of the past forms of verbs they needed for the meaning of their story to be conveyed. It can be also observed that teacher-talk fulfilled here less important function than in, for instance, "One Sentence at a Time" game.

\subsubsection{Roles and interaction in a gamified FL classroom}

"One Word/Sentence at a Time" and "Story Cubes" games helped to provide a unique classroom environment that was characterised by ever-shifting roles of the teacher and her students. First of all, the subjects worked together to narrate a grammatically and logically correct story in the possibly shortest period of time. What is entailed was that not only were they rivals who competed against each other but also collaborators who worked together to defeat their opponents. Secondly, it was also the teacher who served different roles in a classroom. She provided the students with the rules of the games, fulfilling the function of a leader. If her mediation in the game was dispensable since the players managed to continue their stories without her intervention, she remained silent, becoming an observer. Had it not been for the teacher's frequent oral contributions to the game, it would have taken the students even more time to complete their stories. Hence, it is justified to claim that it was also the role of a stimulator that she performed during the lessons.

Apart from offering favourable opportunities of taking on different roles by the teacher and her students, the games provided an array of interactions between the two classroom actors. Having analysed the instances of CI from each of the four transcripts, it is evident that student-talk outweighed teacher-talk. As seen in Figure 1, the subjects played a dominant role in narrating the stories, marginalizing the role of the teacher in classroom discourse.

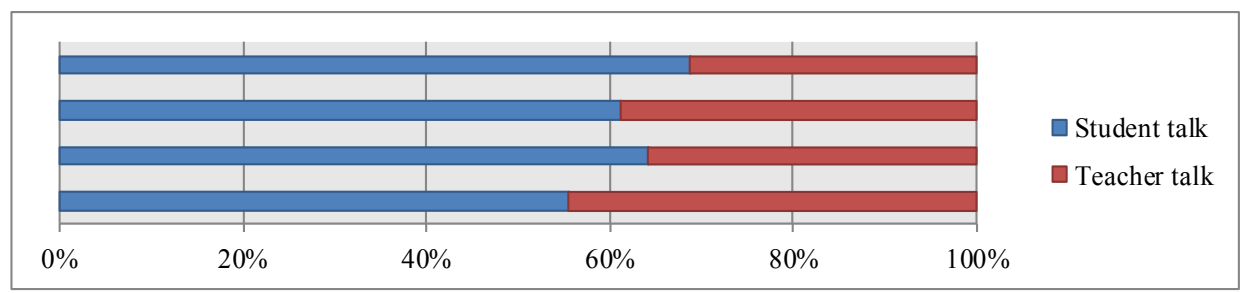

Figure 1. The amount of teacher- and student-talk in the four transcripts

Counting the instances of teacher- and student-talk affords even more revealing insight into the nature of verbal exchanges recorded during the lessons. The games maximized the students' in-class participation and their involvement in storytelling and speaking practice. As a result, the examples of student-talk were more numerous and amounted to 89 turns whereas those of teacher-talk were of less significance and came 
to 58 examples. As far as the participants were concerned, their most vital contribution to the games was that of open-ended response in L2 (67 turns) followed by confusion (19 turns) and an occasional use of Polish (3 turns). The teacher's interventions, on the other hand, could be classified into five different categories, that of encouraging (20 turns), prompting (15 turns), repeating (9 turns), reformulating (7 turns) and instructing (4 turns). The last instance of classroom interaction to be discussed, laugh, was recorded five times and was included in neither student- nor teacher-talk category. The figure below shows the list of classroom interactions noted down in "One Word/ Sentence at a Time" game and two rounds of "Story Cubes" games.

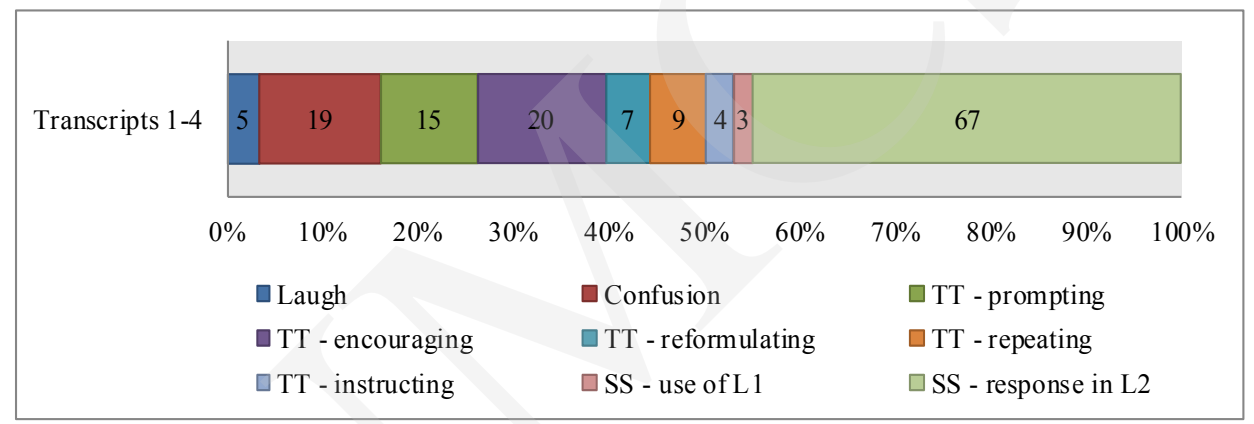

Figure 2. The significance of different categories of teacher- and student-talk in the four transcripts

To be more precise, the instances of student- and teacher-talk could be classified in the following way. As mentioned above, the former included several examples of open-ended response, silence, confusion, laughter, or response in L1. It is still evident, however, that the teacher's assistance during the storytelling-games was crucial since the storytellers' frequent pauses drew her comments on almost every sentence produced by them. She interacted with her students in a very intensive and (inter)active manner by praising or encouraging them, reformulating their utterances, asking questions, giving information or summarising. Table 2 contains selected examples of students' and teachers' utterances.

Table 2. The categories of classroom interaction established by "One Word/Sentence at a Time" and "Story Cubes" games.

\begin{tabular}{cccc}
\hline Transcript & Turn & Category of interaction & Utterance \\
\hline $\mathbf{4}$ & 15 & student-talk; open-ended response & I started crying. \\
\hline $\mathbf{1}$ & 3 & student-talk; silence & {$[\ldots]$ (a moment of hesitation) $[\ldots]$} \\
\hline $\mathbf{2}$ & 31 & student-talk; confusion & {$[\ldots]$ some people $[\ldots]$} \\
\hline $\mathbf{4}$ & 5 & student-talk; laughter & No tak! \\
\hline $\mathbf{1}$ & 15 & student-talk; response in L1 & Aaa $[\ldots]$ no tak, bo koniec zdania. \\
& & & Kropka. \\
\hline
\end{tabular}


Pobrane z czasopisma New Horizons in English Studies http://newhorizons.umcs.pl Data: 26/04/2023 12:23:37

48 Klaudia Gąsior

\begin{tabular}{|c|c|c|c|}
\hline 2 & 25 & teacher-talk; praising & Yes. Great. \\
\hline 3 & 4 & teacher-talk; encouraging & $\begin{array}{l}\text { Okay, perfect. Two sentences at } \\
\text { a time. }\end{array}$ \\
\hline 4 & 14 & teacher-talk; reformulating & $\begin{array}{l}\text { Yes. You threw the phone. What } \\
\text { happened next? }\end{array}$ \\
\hline 3 & 9 & teacher-talk; asking questions & $\begin{array}{c}\text { Maybe what was your friend's } \\
\text { reaction? }\end{array}$ \\
\hline 1 & 14 & teacher-talk; giving information & $\begin{array}{c}\text { We may say full stop. This is the } \\
\text { end of the sentence and the second } \\
\text { person continues }[\ldots]\end{array}$ \\
\hline 2 & 10 & teacher-talk; summarising & $\begin{array}{c}\text { She was sad because the students } \\
\text { were using the phones excessively } \\
{[\ldots] \text { too much. }}\end{array}$ \\
\hline
\end{tabular}

\section{Conclusions}

Since our intention was to prove that the three games chosen for the purpose of the study, that is "One Word/Sentence at a Time" and "Story Cubes", provided an interactive EFL classroom environment and intensified the students' foreign language speech production, a variety of issues connected with the topic of classroom interaction was brought forward in the present paper.

Taking into consideration selected literary investigations, it is already clear that the term of CI can be conceptualized in a variety of ways including, among others, a conversation, a dialogue, or mutual influence. Nevertheless, it becomes evident that a fundamental characteristic of classroom interaction is the emphasis placed on reciprocal linguistic or behavioural adaptations of speakers to that of their interlocutors. Various types of interactions that can be found in classroom environments have been identified by theoreticians and practitioners as instances of CI. Therefore, depending on the approach adopted, their classification might be a source of controversy since not all scholars agree on the identification of a particular interaction as an example of classroom interaction. The most common and, at the same time, most frequently adopted categorisation of CI, however, isolates two major kinds - teacher- and student-talk.

Taking into account the data collected in the study, it can be deduced that "One Word/Sentence at a Time" and "Story Cubes" established an interactive classroom environment. Not only did they vary the teacher's and students' roles during the lessons but also their oral contributions which ranged, in the former case, from praising, prompting, instructing, or reformulating to collaborating, competing or compromising in the latter case. ${ }^{2}$ Moreover, analysing the data gathered allowed one to reach reasonable conclusions that the games substantially increased the 12 students' engagement during in-class game-like activities. It was clearly reflected in the big advantage of student-talk over teacher-talk in the four transcripts.

$2 \quad$ Cf Table 2. 
The action research study, however, had certain limitations. The first of them concerned the participants' linguistic competence. Despite the fact that they were intermediate learners of English, playing "Story Cubes" games took them more time than it was initially outlined in lesson plans. As mentioned above, it was caused either by their insufficient linguistic knowledge or by the lack of picture-related ideas which they could base their stories on. As a result, the classroom time allowed the participants to play the games only twice. The second limitation referred to the length of the study, which lasted only for a period of two weeks. Thus, not all possible instances of classroom interaction could have been recorded. The last limitation was connected with the availability of the teacher. Since there was a considerable amount of group work during the four lessons, the teacher could not always be at the students' disposal. It means that not all the students could benefit from the teacher's help as there might have been other individuals who needed some guidance at a particular moment.

To sum up, for successful foreign language teaching to take place, a variety of interactive situations should be fostered since it is not only a language, but also a set of social skills and content knowledge that underpin FL learning. Such a goal may be achieved by diversifying classroom work and providing both students and teachers with different roles to perform in the classroom. It is probably the most viable solution for students to develop not only as foreign language users, but also as well-cultivated and refined citizens.

\section{References}

Beutel, Denise. 2010. "The Nature of Pedagogic Teacher-student Interactions: A Phenomenographic Study." The Australian Educational Researcher 37 (2): 77-91.

Boarcas, Camelia. 2014. "Introducing Games in ESP Classes." Economics, Management, and Financial Markets 9: 376-381.

Bokhove, Christian. 2018. "Exploring Classroom Interaction with Dynamic Social Network Analysis." International Journal of Research \& Method in Education 41(1): 17-37.

Brown, Douglas H. (2001). Teaching by Principles. An Interactive Approach to Language Pedagogy. New York: Longman.

Byrne, Donn. 1987. Techniques for Classroom Interaction. Essex; Burnt Mill; Harlow: Longman Group UK Limited.

Cockett, Stephen, and Fox, Geoff. 1999. Keep Talking!: Learning English through Drama, Storytelling and Literature. Kraków: Wydawnictwo Naukowe Wyższej Szkoły Pedagogicznej.

Chiu, Ming. M. 2013. “Classroom Interactions between Students.” In Sociology of Education: An A-to-Z Guide, ed. James Ainsworth, 125-127. Thousand Oaks; California: SAGE Publications, Inc.

Creemers, Bert, and Leonidas Kyriakides. 2008. The Dynamics of Educational Effectiveness. A Contribution to Policy, Practice and Theory in Contemporary Schools. London and New York: Routledge. 
Ellis, Rod. 1988. Classroom Second Language Development. Hertfordshire: Prentice Hall International UK Ltd.

Flanders, Ned A. 1970. Analysing Teacher Behaviour. London: Harper and Row.

Hall, Joan Kelly. 1995. “'Aw, man, where you goin'?': Classroom Interaction and the Development of L2 Interactional Competence." Issues in Applied Linguistics 6 (2): 37-62.

Hanghoj, Thorkild. and Brund, Christian E. 2011. "Teacher Roles and Positionings in Relation to Educational Games." In Serious Games in Education: A Global Perspective, ed. Bente Meyer and Simon Egenfeldt-Nielsen, 123-136. Arhus: Aarhus University Press.

Howe, Christine, and Manzoorul Abedin. 2013. "Classroom Dialogue: A Systematic Review across Four Decades of Research." Cambridge Journal of Education 43 (3): 325-356.

Li, Li, Shouhui, Zhao, and Chen Xinying. 2011. Beyond research: Classroom interaction analysis techniques for classroom teachers. 4th Redesigning Pedagogy International Conference, Singapore, 30 May to 1 June 2011, 1-18.

Losey, Kay M. 1995. "Mexican American Students and Classroom Interaction: An Overview and Critique." Review of Educational Research 65 (3): 283-318.

Łęska, Krystyna. 2008. Teacher's Use of Interactional Patterns in a Foreign Language Classroom and Gains in Students' Oral Fluency. Częstochowa: Wydawnictwo Wyższej Szkoły Lingwistycznej.

McCrory Calarco, Jessica. 2013. "Classroom Interactions: Teachers and Students." In Sociology of Education: An A-to-Z Guide, ed. James Ainsworth, 123-125. Thousand Oaks; California: SAGE Publications, Inc.

Nisa, Sinta Hoerun. 2014. "Classroom Interaction Analysis in Indonesian EFL Speaking Class." English Review: Journal of English Education 2 (2): 124-132.

Nunan, David. 1987. "Communicative Language Teaching: Making It Work.” ELT Journal 41 (2): 136-45.

Ohlberger, Stephanie, and Claas Wegner. 2013. "Vivid Teaching through the Use of Various Types of Interaction.” Teaching Science 59 (4): 35-38.

Rivera, José David Herazo. 2010. "Authentic Oral Interaction in the EFL Class: What It Means, What It Does Not." Profile 12 (1): 47-61.

Scott, P. and J. Ametller. 2007. "Teaching Science in a Meaningful Way: Striking a Balance Between 'Opening up' and 'Closing Down' Classroom Talk.” School Science Review 88 (324): $77-83$.

Seedhouse, Paul. 1996. "Classroom Interaction: Possibilities and Impossibilities." ELT Journal Volume 50 (1): 16-24.

Siek-Piskozub, Teresa. 1994. Gry i zabawy w nauczaniu języków obcych. Warszawa: Wydawnictwo Szkolne i Pedagogiczne.

Skarbo, Marit Solem, and Karianne Skovholt. 2017. "Teacher Formulations in Classroom Interactions." ScandinavianJournalofEducationalResearch.DOI:10.1080/00313831.2017.1324904.

Skukauskaite, Audra, Rangel, Jessica, Garcia, Rodriguez Lisa, and Denise Krohn Ramon. 2015. "Understanding Classroom Discourse and Interaction: Qualitative Perspectives." In Handbook of Classroom Discourse and Interaction, ed. Numa Markee, 44-59. West Sussex: John Wiley \& Sons, Inc. 
Pobrane z czasopisma New Horizons in English Studies http://newhorizons.umcs.pl Data: 26/04/2023 12:23:37

Smith, Heather, and Steve Higgins. 2006. "Opening Classroom Interaction: The Importance of Feedback." Cambridge Journal of Education 36 (4): 485-502.

Tsui, Amy B. M. 1995. Introducing Classroom Interaction. London; New York: Penguin Books Ltd.

Tsui, Amy B. M. 2001. “Classroom Interaction.” In The Cambridge Guide to Teaching English to Speakers of Other Languages, ed. Ronald Carter and David Nunan, 120-126. Cambridge: Cambridge University Press.

Wieser, Clemens. 2013. “Classroom Dynamics.” In Sociology of Education: An A-to-Z Guide, ed. James Ainsworth, 122-123. Thousand Oaks; California: SAGE Publications, Inc.

Wright, Andrew, Betteridge, David, and Michael Buckby. 2006. Games for Language Learning, Cambridge: CUP

Van Lier, Leo. 1988. "Classroom Interaction Patterns of Foreign Language Teachers ERIC/ CLL.” News Bulletin 11 (2): 3-6.

https://www.storycubes.com/. 